\title{
HAZARD PROPHYLAXIS AND BEHAVIOURAL ADDICTIONS OF CHILDREN AND TEENAGERS ON THE EXAMPLE OF CONDUCTED PUBLIC DUTIES "TEENAGERS AND CHILDREN - SAFE IN THE WEB SINCE TODAY" CARRIED OUT BY THE TRAINING AND THERAPEUTIC CENTRE SELF
}

Sabina Południak', Kinga Ostrowska-Magoń2

\section{Abstract}

The aim of this thesis is to present the threats arising from the Internet usage, with the special account of behavioural addictions of young people. The second aim is to introduce proactive activities which have been implemented to schools in the Podkarpacie region since 2016 within the scope of public duties "Teenagers and children - safe in the Web since today" ("Młodzież i dzieci - od dziś bezpieczni w sieci,") being carried out by the Training and Therapeutic Centre SELF due to the resources of the National Health Programme during 2016-2020

Key words: behavioural addictions, hazard prophylaxis, virtual addictions, Media, National Health Programme for 2016-2020.

\section{Introduction}

For modern children and teenagers the Internet is the indispensable meta-medium in every day communication and social functioning. Potential addictions and dangers are being strengthened and become diversified together with continual technological development and deepening conformism, especially among young network users. Yet, it

\footnotetext{
Sabina Południak, e-mail: sabinapoludniak@gmail.com

2 Kinga Ostrowska-Magoń - psychologist, Training and Therapeutic Centre SELF (Poland), e-mail: projekty.self@gmail.com
} 
is essential to improve the level of knowledge all the time and the awareness of young users of the new media. However, it is also important to pay attention to the upbringing surrounding of a young person, how they function and acquire social abilities about potential dangers, the ways how to counteract and prevent them and the need to cooperate with all the entities. The majority of teachers and social research underline that in the era of such fast technological changes adults are only digital immigrants. Directing educational activities for adults seems to be the key to effective proactive activities.

Supporting local governments and their organizational units in raising the level of IT competence both in the school education of children and teenagers, teachers as well as parents is extremely important.

Delegating this type of activities in the scope of, for example, governmental projects, to units being out of public financial sector such as legal people and non-governmental organizations lets the cooperation with the units specialising in the particular area of activities. Thereby, it improves the effectiveness of taken activities.

\section{Virtual addictions and dangers in the context of intergenerational relations and developmental conditioning}

As suggested by Prensky [2001,p.1-13] social division into digital natives and digital immigrants perfectly depicts immeasurable differences of children's reality from that reality, in which their parents and other adults, who are responsible for the process of upbringing, are active. It goes without saying that by contrast to their attendees, adults have to acquire new technologies as the secondary ability, a particular addition to the reality which is in contrary to children, for whom virtual world is the basic component of the reality. It affects visible differences in fluency of functioning in the digital world and the lack of full understanding of its mechanisms, and what is connected with these aspects, radical decline of control over children's behaviour, lack of awareness and impossibility to control virtual activity of their offspring. It is especially alarming and worrying in the scope of numerous threats which children and teenagers face in the cyber world.

From the perspective of the complex project prepared for social workers [Lizut, 2014, p. 66-84], hazards connected with the digital technology and the Web can be looked at from a few angles:

- physical ailments (visual impairment, osteo problems, RSI (Repetitive Strain Injury) resulting in repetition of certain movements, including Carpal Tunnel Syndrome (CTS), so called Blackberry Thumb or a Player's Thumb;

- addiction and about-addiction dangers (computer games addictions, Internet erotomania, information and news addiction, social contacts addiction, cyberchondria which means constant browsing for information concerning illnesses);

- cyberbullying (feeling of anonymity and impunity, variation according to Willard: flaming, online bullying, cyberstalking, discrediting, posing as somebody, excluding);

- dangers for the cognitive development (so called digital dementia - Spitzer[2013, p. 179], shallow information processing, blocking memory structures practises and creating new nerve connections in brain, reproductive learning, problems with finishing undertaken activity - its continuous disruption by checking multimedia and the Web, getting away from the traditional way of linear thinking - Carr [2010p. 5-89];

- social development dangers (limiting face-to-face contacts, oversimplifying social relations, limiting time spent together in the real life);

- undertaking risky activities (patostreaming, spreading knowledge and wider access to psychoactive substances, spreading information hazardous for health, for example, promoting anorexia and socially unfavourable ones, for instance, racists or aggressive content, recruiting to sects, suicidal attempts); 
- abuses and improper sexual patterns (grooming, sexting, paedophilia, obtaining photos, unintended sexual sources collection, facilitating intentional access).

Pyżalski J. [2010, p. 118-137] by presenting the theoretical outline and the research results of Polish teachers and pupils in context of electronic aggression, pointed his attention to non-uniformity and penetrating its different forms.

Electronic aggression is often analysed in the very simplified way, which does not include diversity of occurrences involved in this category, their characteristics and conditioning. People analysing cyber aggression concentrate usually on the very fact of the applied device - which means new communication technologies, without any closer analysis of different sub-types electronic aggression and potentially assisting mechanisms.

The attention was directed to social and psychological mechanisms, which can appear both at the offender's side and a victim's side. Presenting teachers' believes referring to their own digital competences is also essential. The considerable part of teachers claims that the abilities, shown by students on how to use a computer overcome their own competences. Pyżalski poses a question if this conception applies to the reality and he implements that for sure it has got its own rendition into the way of thinking about aggression and its consequences. If students are fluent in using modern IT technologies and a particular teacher has a feeling referring to enormous shortage of knowledge in this matter - he can feel especially endangered in such a situation when students would use new technologies to create aggression. He also states that teachers' knowledge on the electronic aggression and ways how to fight with it is enormous.

Only $12,5 \%$ of the surveyed people took part in a training course about cyber aggression. Additionally, every fifth teacher from this group claims, that training courses did not give them any knowledge possible to use in practice.

In order to understand digital media and the Web's influence on the development of a young person, it is crucial to analyse closer two basic perspectives - biological and socio-relative.

The biological perspective focuses on the fact that our brain should obtain diversified experiences and this is the base of its development and the proper functioning [Kalat, 2006, p. 108-123]. The simplest proof of the huge influence of an undertaken activity on the brain structure are changes in its organisation visible in body's functioning. For example, the so called "pianist's cramp" resulting from frequent practice of playing an instrument - intense exercises of a brain's part, responsible for fingers stimuli reception, cause its growth and covering parts of the brain receiving a signal from surrounding body parts. As a result, fingers' movements become clumsy [Byl, McKenzie, Nagarajan, 2000, p. 302-309]. Nervous system and personality shape themselves and develop most intensively during children and teenagers' lives. Together with the obtained every day experiences nervous connections develop, practised abilities are very quickly remembered and mastered; habits over-learning appear to be much faster than in the case of adults. What is more, the brain has also the greatest recovery ability after injuries. Children's plasticity, on one hand, means the greater vulnerability to any unfavourable stimuli and experience to which a developing psyche of a young person is specially sensitive, on the other hand, it means also vulnerability to proactive activities, the ability to over-learning which is faster than in the case of adults and shaping new patterns of behaviour. That is why, of the utmost importance is the role of the so called "alternative prophylaxis" combined, among others, with more effective free time management. It is essential to remember, when these matters are mentioned, that inability to use free time creatively results in too immense preoccupation with the virtual world and abandoning the will to undertake diverse activities. It is worth remembering that unused nerve connections in the brain disappear - that is why it is very important to provide a child with different stimuli, in order to enable the young person to have an optimal development [Bee, 2004, 
p.325-361].

The socio-relative perspective concentrates on the basic function of relations with other people, which are built on the basis of bonds with parents, as a proper personal and general development. [Bowlby, 1973; Ainsworth, 1978]. Research shows that children's social development is connected with parents' sensitiveness to their needs and consequence in actions [Fagan, 2000, p. 592-612]. The kind of relation, being built between parents and children influences on the way of offspring behaviour in conflict-like situations. Thus, they can strive for direct problem solving or implement strategies based on domination, avoiding direct confrontation and engaging themselves in the larger amount of disputes [Ben-Ari, Hirshberg, 2009, p. 59-82]. The research also indicates, that the specific kind of created relations in a family influences the ability to control oneself in contacts with other people [Dereli, Karakus, 2011, p. 731-744]. This data is immediately reflected by the behaviour of violent offenders, including cyber violence. The approach based on relation improving pattern and social competence growth, both for parents and children, forms a chance to limit the number of violent activities, shapes the ability to self-control and strengthens the strategy of dealing with problems based on solving, cooperating and supporting each other.

From the perspective of creating effective proactive strategies of activities, the awareness of social and psychological conditioning of an immature and not yet shaped personality of a young person, who is especially vulnerable to numerous dangers steaming from modern technologies and embedding proactive activities in a system connected with adults' education is vital. However, on the other hand, [P. Plichta, 2012, p.135 -152], we should remember about the fact that these are also the tools used to shape identity, support interpersonal contacts, fill up free time, make decisions and so on. The enculturative aspect of the Web forces pedagogues to be profoundly prepared to support teenagers, or at least to make an attempt to understand teenagers behaviour within this area. It is necessary to provide technical facilities at schools, and what is more, teachers have to have particular competences and qualification, both in the technical and interpretation aspect.

In the scope of this education, it is impossible to stay dominated by noticing only potential hazards, but to aim to use the Web to support the young people's competence and to maintain good proportions between online and offline existence.

A. Borkowska, M. Witkowska [2017, p.11-36]by describing the meaning of social media at school, underline also their numerous assets and, as well, their huge influence on the development of many sectors of teenagers' lives. Not everything what is connected with the Media poses risk. These conclusions can be promising. The authors imply, among others that they:

- help to develop mindfulness and critical thinking and teach the way of communication by facing different attitudes, values and behavioural patterns;

- help to develop many useful abilities such as linguistic and literary ones - reflected in the shortness of speech or reasoning through the virtual world. Social online games help with coordination and motor activities, but also they teach cooperation and team relations;

- support the development of social and civil competences by broadening friends' group and by participation in forums, charity, social and political actions and activities;

- are also inspirational by enabling to create new music and film items, write blogs and many other.

Prophylaxis in practice on the example of the proactive programme, implemented due to the execute public duties "Teenagers and children - safe in the Web since today" ("Młodzież i dzieci - od dziś bezpieczni w sieci") being carried out by the Training and Therapeutic Centre SELF 
The above proactive activities have been introduced since 2016. Until now, five editions have been accomplished. This programme will have its own follow-up also in 2019. It has been financed by the resources coming from the National Health Programme for 2016-2020 - the Fund Solving Hazard Problems. The core of this programme in the implemented scope by The SELF Centre is the accomplishment of universal prophylaxis of hazard and other behavioural addictions directed to children and teenagers, with the special impact of the Internet and computer abuse.

The first edition was carried out during the period of 1st September 2016 till 31st December 2016 by the Training and Therapeutic Centre SELF s.c. Similarly, the second edition was carried out from 1st February 2017 to 31st December 2017 and the third one from 1st September 2017 to 31st December 2017. Two editions in 2018 - these are as follows - the 4th edition during the time from 2nd January 2018 to 31st December 2018 and the 5th edition between 1st September 2018 till 31st December 2018 were carried out by the Training and Therapeutic Centre SELF T. Kobylański s.c.

The first edition was carried out in 10 schools in the Podkarpacie region, including 6 primary schools and 4 lower secondary ones. It covered 24 classes, from the 4 th grade to the 6th grade. In total, for this age group, 144 hours of proactive educational classes were carried out. With lower secondary school students (1st grade to 3rd grade) 96 hours of classes have been carried out in 16 classes. In those schools 732 children and teenagers were involved in this programme. What follows, 80 hours of discussion panels with class tutors, teachers, pedagogues and school head teachers were carried out in the scope of 2 educational hours.

In the second edition 720 hours of proactive educational classes were conducted for children and teenagers and 120 discussion panels with class tutors, teachers, pedagogues and school head teachers were carried out in 30 schools in the Podkarpacie region. The programme covered 17 primary schools including 68 classes ranging from the 3 rd to the 6th grade; 9 lower secondary schools with 36 classes from the 1 st grade to the 3rd grade; and secondary schools' students from the 1 st grade to the 3rd grade/from the 1 st to the 4th grade for students from the Technical Secondary school in 4 different schools for 16 classes in total.

In the third edition proactive educational classes were carried out for the students from the primary school ranging from the 4 th grade to the 7 th grade in 15 primary schools for 60 classes in general. It amounted to 360 hours. 120 hours were conducted for the lower secondary school students from the 2nd grade to the 3rd grade in 10 schools for 20 classes in total. Secondary school students from the 1st to the 3rd grade and students from technical secondary school from the 1 st to the 4 th grades were covered by these activities in two schools in 8 classes. Moreover, 88 discussion panels with class tutors, teachers, pedagogues and school head teachers were carried out in 27 schools.

The fourth edition was accomplished in 25 primary schools. It embraced 1654 students from the 4th to the 7th and 8th grades, in 100 classes, amounting to 600 proactive educational hours of classes. What is more, 200 hours of discussion panels were organised with class tutors, teachers, pedagogues and school head teachers for 100 people.

The fifth edition was carried out in further 7 primary schools for 542 students from the 4th to the 7th grades, in 35 classes, amounting to 210 proactive educational hours of classes. 35 hours of discussion panels were organised with class tutors, teachers, pedagogues and school head teachers for 35 people in general.

The main objective of the above mentioned projects was to conduct the activities aiming at conscious and safe computer and the Internet usage by children and teenagers taking part in the project.

The detailed goals, although slightly varying among particular age groups, concentrated around the following:

- rising participants' awareness concerning the risk online and the implementation of 
safe methods for computer and the Internet usage;

- counteracting the addiction to computer games and the Internet and cyberbullying phenomenon as well;

- creating proper and secure functioning in the digital environment;

- rising awareness referring to the usage of methods applied in case of facing online dangers;

- creating a healthy and active lifestyle and promoting diverse alternative forms of spending free time, without addictions;

- publicising programmes at schools concerning prophylaxis and education in scope of behavioural addictions, especially e-addictions;

- broadening the teachers and school head teachers' awareness relating to dangers hidden in the virtual world for the proper students' development;

- getting to know new forms and methods of work, in the aspect of proactive and educational function of school, and developing and implementing prophylaxis strategy of behavioural addictions on the school premises as well.

The agenda of the proactive workshops being carried out within the project, was created on the basis of the assumptions of the American programme All Stars. It includes the following factors: pleasant school atmosphere, proper communication between students and teachers, teachers' expectations referring to students adjusted to children's possibilities and clear rules of behaving at school.

In this programme, the following activities are applied:

- tasks carried out in classes are the base of the programme. Their intensity is very much diversified: starting form four lessons during one year, through a few (several) meetings in two subsequent years of learning, up to several hundred hours of classes extended over three years or as it is stated in the programme -during all years of learning.

- active methods of running classes used in the programmes include: work in small groups, discussions, tasks solving activities, games, preparing videos, artistic works, presentations and exercises.

- to accompany the above mentioned tasks, discussion panels for teachers, class tutors, pedagogues and school head teachers for each and every school are going to be organised in order to analyse and draw conclusions concerning workshops activities, which should help to create pleasant atmosphere in the school environment.

To carry out tasks, in each of the five editions, single six-hour workshops ( $1 \mathrm{~h}=45$ minutes) were conducted at schools, for chosen classes.

The subject of these activities was adjusted appropriately to the age group, needs and students' developmental possibilities with taking account of their interests, predispositions and preferences. It also concerned the ways which may help students to avoid dangers lurking online, becoming a cyber-violence victim or an offender. The students were introduced to the rules of using the Internet in the safe way. They were encouraged, as well, to ask professionals for help in case of appearance any problems or worrying situations taking place in cyber-reality.

Special emphasis was put on the subject area concerning the cyber-violence counteracting, which is spreading more and more visibly among children and teenagers, who almost every day face its online indications as victims, witnesses or even offenders. The workshop activities also aimed at reacting against aggression and peer pressure and violence. During the classes, students got to know the reasons of aggression and violence, the ways how to relieve them, how to distinguish and show personal emotional states both in the real and online reality. Also, during the classes together with students, the norms and regulations were set up referring to their safe behaviour at school and on the Internet. The classes were conducted with the usage of the active working tech- 
niques, among others with the usage of game pedagogy, psychodrama or protective methods based on competitive assumptions. The applied forms of cooperation included both team and individual work.

The classes were carried out in each and every school taking part in the project. They were run by therapists possessing the proper education and experience in this subject.

Meetings with teaching staff at schools were held immediately after the finished proactive-educational workshops in each class team in order to analyse the carried out activities. The therapists who ran the workshops, presented their deductions and observations and together with teaching staff they drew conclusions and recommendations to further proactive-educational actions.

Every year the programme was being evaluated. It was conducted in a few ways. Project's evaluation lasted throughout the time of its process and its main aim was the assessment of the effectiveness of the carried out activities, accuracy in the choice of these activities and usefulness of the obtained knowledge. It allowed to implement, on an ongoing basis, all the necessary modifications and flexible adjustment of the methods and forms, used in the project, to the participants' requirements.

What is more, the goal of the evaluation was to gather information which would be introduced to the scope of risky online behaviour and addiction to computers and the Internet prophylaxis among children and teenagers. It enabled to draw conclusions and make comments and recommendations for further activities undertaken by the proponent within the area of proactive activities.

In order to obtain reliable and comprehensive data, the proponent chose research methods which made it possible to gain the complete view of the tested reality. From the perspective of the research effects and collected information, apart from the above mentioned observation, was the interview.

The Training and Therapeutic Centre SELF carried it out on the base of the previously prepared survey - conversations. The representatives from schools taking part in the project were chosen at random at its end. Students and their teachers, who were invited to participate in the interview, had to point out the strengths and weaknesses of the project and could speak their minds about their future expectations concerning similar ventures. The applied research method, thanks to the direct contact with the examined people, made it possible to appreciate the project from the perspective of both participants and implementers as well. Project's participators chosen for the interview, answered the questions referring to:

- the most useful issues brought up during the carried out programme;

- the least useful issues brought up during the carried out programme;

- substantive assessment of the coaches running the programme;

- assessment of the way of knowledge passing;

- knowledge increment referring to the safe usage of a computer and the Internet;

- factors contributing to the knowledge increment referring to the safe usage of a computer and the Internet;

- suggestions concerning changes in the way of conducting or subject area of such activities in the future. During the first edition twenty interviews were carried out, during the second and third edition forty, twenty and ten interviews during the fourth and the fifth respectively.

On the basis of the interviews (directed discussions) it can be concluded that the conducted proactive programme fulfilled the expectations of both students taking part in the classes, and their teachers, class tutors and pedagogues as well. As class tutors underlined, a very significant part of a project for them was the possibility of analysing the conclusions and prospective worrying signals referring to students just after the 
workshops. They pointed out the high value of discussion panels during which different points of view on the subject of particular students could be confronted, suggestions of specific activities aimed at individual people or the whole classes were formulated. Students, who took part in discussions emphasised that the workshop-like form of work together with practical activities let them remember the analysed topics better, comparing to common participation in standard talks or lectures on a similar subject. The real strength of the conducted activities, according to the majority of students (approximately $70-80 \%$ ), was the possibility of team work allowing for setting up the rules of the safe usage of the Net and the ways of spending free time without a computer. The content, the way of its passing and the preparation level were assessed as high. The content, because of its adjustment to each age group, was clear. The essential factor, from the students' perspective, was the possibility of asking questions on an ongoing basis during the classes and trying to find a proper solution or an answer together. With reference to the future activities concerning the prophylaxis of behavioural addictions the following issues were mentioned: conducting workshop activities as a form of meeting series (for example 2-3 times a year) and introducing activities providing children and teenagers with the ideas how to manage effectively their own time, including the active and sporty way of doing so.

\section{Summary}

The obtained conclusions and recommendations imply the fact that conducting proactive and educational activities for children and teenagers from primary schools participating in the project from the Podkarpacie region, contributed to the rise of knowledge in the area of behavioural addiction mechanisms, protective factors and techniques referring to the fact how to deal with the difficulties of free time management. Workshops and discussion panels proved a preliminary diagnosis that one of the main dangers which young people face nowadays is cyber reality threats and the risk of becoming addicted to new media, including the Internet (especially social media), gambling and computer games. One of the reasons of this fact is the attractiveness of the virtual world for young receivers. It is strongly connected with the need to create continually newer and newer, more interesting forms of spending free time by children and teenagers and shaping the ability to manage their time effectively. In the future proactive activities, it is vital to pay attention to the possibility of students' interaction referring to the subject of creating the principles of safety and improvement of their social competences, especially in the field of communication with others and developing the ability to be assertive and to resolve conflicts. Teaching children and teenagers the techniques of time management and gradual implementation of the active and sporty forms of spending free time with peers is essential from the perspective of the participants and implementers of the project.

The new challenge is connected with working in the area of dangers resulting from the growing popularity of mobile devices.

\section{REFERENCES:}

AINSWORTH, M.D.S.,BLEHAR, M.C., WATERS, E., WALL, S. (1978). Patterns of attachment: A psychological study of the strange situation. Hillsdale, $\mathrm{NJ}$ : Erlbaum;

BEE, H. (2004) Psychologia rozwoju człowieka, Rozdział 11. Rozwój fizyczny i poznawczy w okresie dorastania, Wyd. ZYSK i SK-A, Poznań;

BEN-ARI, R., HIRSHBERG, I. (2009). Attachment Styles, Conflict Perception, and Adolescents' Strategies of Coping with Interpersonal Conflict.NegotiationJournal, 25(1), 59-82. DOl:10.1111/j.1571-9979.2008.00208.x;

BORKOWSKA, A., WITKOWSKA, M. (2017), Media społecznościowe w szkole, NASK - Państwowy Instytut Badawczy, Warszawa;

BOWLBY, J. (1973). Attachment and loss: Vol.1. Attachment. New York: Basic Books;

BYL, N.N., MCKENZIE, A., NAGARAJAN, S.S. (2000). Differences in somatosensory hand organization in a 
healthy flutist and a flutist with ocal hand dystonia: A case report. Journal of Hand Therapy, 13, 302-309. (5); CARR, N., (2010). The shallows. What the Internet is doing to our brains,wyd. W.W Norton \& Company, New York, London;

DERELI, E., KARAKUS, 0. (2011). An Examination of Attachment Styles and Social Skills of University Students. Electronic Journal Of Research In Educational Psychology, 9(2), 731-744;

FAGAN, J. (2000). African American and Puerto Rican American Parenting Styles, Paternal Involvement, and Head Start Children's Social Competence. Merrill-Palmer Quarterly, 46(4), 592-612;

HOLTKAMP, J. (2010), Co ogłupia nasze dzieci?, Wydawnictwo Salwator, Kraków;

KALAT, W.J. (2006), Biologiczne podstawy psychologii. Rozdział 5. Rozwój i plastyczność układu nerwowego,Wyd. PWN, Warszawa;

LIZUT, J. (red.) (2014), Nowa polityka społeczna. Zagrożenia cyberprzestrzeni. Kompleksowy program dla pracowników służb społecznych., Wydawnictwo Wyższej Szkoły Pedagogicznej im. J. Korczaka, Warszawa;

PLICHTA.P. (2012), Miejsce nowych mediów w nauczaniu i wychowaniu jako ważny obszar przygotowania praktycznego kandydatów do pełnienia roli nauczyciela i wychowawcy, w: D. Podgórska (red.), Dobre praktyki pedagogiczne szansą innowacyjnej edukacji, Wydawnictwo Naukowe WSP, Łódź;

PRENSKY, M., Digital Natives, Digital Imigrants, On the Horizon 2001, MCB University Press, Vol. 9. No 5, www. marcprensky.com;

PYŻALSKI J. (2010), Polscy nauczyciele i uczniowie a agresja elektroniczna - zarys teoretyczny i najnowsze wyniki badań, w: M. Jędrzejko, D. Sarzała (red.) Człowiek i uzależnienia, Pułtusk - Warszawa. Akademia Humanistyczna im. Aleksandra Gieysztora, Oficyna Wydawnicza ASPRA-JR;

SPITZER, M. (2013), Cyfrowa demencja. W jaki sposób pozbawiamy rozumu siebie i nasze dzieci., Wyd. Dobra Literatura, Słupsk;

SIEDLANOWSKI P. (2018) Homo crudelis? Patostream - kolejna patologia w sieci, Homo crudelis? Anotherpathology in the network, w: Woźniak J., Chmielewski M., Sonak D., Szajda A, Podlecki M. Szczygieł A. (red.) Biuletyn Edukacji Medialnej, Katedra Współczesnych Form Przekazu Wiary, Wydział Teologii Katolicki Uniwersytet Lubelski Jana Pawła II. Lublin;

WILLARD, N. E. (2007), Cyberbullying and Cyberthreats: Responding to the Challenge of Online Social Aggression, Threats, and Distress, Research Press;

WOLAK, J., MITCHELL, K., FINKELHOR, D., Does Online Harassment Constitute Bullying? An Exploration of Online Harassment by Known Peers and Online only Contacts, "Journal of Adolescent Health", 41/2007, 6 (Supplement), s. 51-58;

The final raports on the conducted public duties "Teenagers nadchlidres - safe in the Web sinse today" - 1st 5th edition carried out by the Training and Therapeutic Centre SELF during 2016 - 2018. 